\title{
Jens-Morten Hanssen: Ibsen on the German Stage 1876-1918. A Quantitative Study. Narr Francke Attempto Verlag, Tübingen, 2018 (Modernes Theater: Schriftenreihe, Band 53)
}

\section{By Thomas Mohnike}

To cite this article: By Thomas Mohnike (2020): Jens-Morten Hanssen: Ibsen on the German Stage 1876-1918. A Quantitative Study. Narr Francke Attempto Verlag, Tübingen, 2018 (Modernes Theater: Schriftenreihe, Band 53), Ibsen Studies, DOI: 10.1080/15021866.2020.1757298

To link to this article: https://doi.org/10.1080/15021866.2020.1757298

\section{Published online: 06 May 2020.}

\section{Submit your article to this journal $\square$}

\section{Џ Article views: 3}

Q View related articles ¿

\section{View Crossmark data $\widetilde{ }$}




\section{REVIEW}

Jens-Morten Hanssen: Ibsen on the German Stage 1876-1918. A Quantitative Study. Narr Francke Attempto Verlag, Tübingen, 2018 (Modernes Theater: Schriftenreihe, Band 53)

Why should one set out today to prove the importance of Henrik Ibsen for the German stage and international modern theater? Hasn't the subject been all too well researched for many years? At the occasion of the premiere of one of Ibsen's plays on January $8^{\text {th }}, 1893$, the German playwright Hermann Sudermann is said to have exclaimed: 'Vom Norden kommt uns das Licht' ['From the North comes the light to us'], quoting Voltaire's famous appreciation of the Russian Tsar Catherine II. Today, Sudermann told his audience, it is Scandinavian modern literature that brings light to Germany, and the critic Siegfried Jacobsohn explained some years later: 'Das eine Licht hieß Björnson, das andere hieß Ibsen' ('One light was called Bjørnson, the other Ibsen'). Around 1890, so the story goes-told for example in Bradbury and MacFarlane's classical study on Modernism ( $\left.{ }^{2} 1991\right)$ - Ibsen became the symbol for modern theater as the result of a 'concerted launching' of his Ghosts by Théatre libre activists in Paris, Berlin, Vienna and London, because it both best served their theatrical aspirations and at the same time most evidently expressed the spirit of the age, they [hereby] succeeded in transforming Ibsen from a dramatic author of modest Scandinavian dimensions into one of imposing European proportions' (500).

Why, thus, go back to a subject that appears to be one of the most researched themes of modern Scandinavian theater? In his study, inspired by theorists like Franco Moretti, Jens-Morten Hanssen answers: first, new quantitative approaches to culture 


\section{REVIEW}

might be interesting means to corroborate knowledge acquired in other ways - and as such, this is already important. Second, new data is always creating new insight and invites us to rethink or put into perspective many of the stories that we take for granted. In this way, Hanssen's quantitative approach proves what we of course already know-that Ibsen enjoyed considerable success on the German stage and that this success had an impact on his subsequent recognition as a world-renowned author-but shows that history did not necessarily follow the favorite storyline employed today by historians of modernism. To mention but one result here: Ibsen's success was not primarily due to his work's modernity, but to its adaptability to the needs of commercial theater, not at least thanks to sometimes very loose unauthorized translations. We will come back to a discussion of these results below.

Jens-Morten Hanssen's study has its origin in a comprehensive database of potentially all productions of Ibsen's plays worldwide, hosted and developed by the University of Oslo's Ibsen Center, a project for which Hanssen was an important actor. The database is an impressive work in itself, including information on 23,262 events at the time Hanssen finished his work. The database is based on the repertory database that was created as part of the centenary of Ibsen's death in 2006 and was later transferred to the University of Oslo's Ibsen Center. The transfer included, as Hanssen explains, a change in software and database structure. The Ibsen Center decided to take on the software AuStage, developed for the Australasian Drama Studies Association, a powerful tool constructed around a relational database that allows queries centered around actors, events, places, languages, and much more. It can be used to analyze the social networks of connected actors and their historical transformations that made the international and always localized Ibsen into a global phenomenon from its beginnings until today. It delivers statistics about the frequency of productions of specific works worldwide, languages and much more. Hanssen's study is the first booklength attempt to explore the possibilities of historical research 


\section{Ibsen Studies}

offered by the database, taking the case of German-language productions from the first instances in 1876 to the end of World War I as its sample, and shows the value of such data. Of course, Hanssen supplements data analysis with qualitative research in order to be able to interpret the results.

As Hanssen remarks, quantitative data is no less subjective than qualitative data: It is pre-structured by the database model. Unfortunately, Hanssen does not go far beyond merely noting this truth, and fails to discuss its pitfalls and biases thoroughly enough. In my view, two central problems impair the results. First, it seems to me, is that the database model inherited from AuStage does not account for changing historical borders and national memberships - an aspect that might have been less relevant in the case of twentieth-century Australia, but is decisive for the German-language stage under study, whose political geography profoundly differed from today's. Second, the creation of data is not sufficiently documented. For example, when searching for productions of Ibsen's theater in Germany in the period of Hanssen's study on <https://ibsenstage.hf.uio.no/pages/ browse/map/country $>$, we find no productions in Strasbourg or Metz. These can, however, be found when looking for French productions, even though the two cities were German at the time. Hanssen tries to circumvent the problem by focusing on German-language productions, thereby proposing a transnational approach that is quite appropriate to the historical situation. Nevertheless, the database appears to have some shortcomings in recording languages in the event data: as I read Hanssen's book, I was intrigued by the relative emptiness of parts of maps and tables in regions that today are no longer German, but rather French or Polish. However, neither Hanssen nor the IbsenStage website give sufficient explanations on how the data was acquired-is the absence of events in the database caused by an historical absence of interest in Ibsen at the time, or were the databases constructed based on today's political borders, meaning that the French and Polish cities are not yet sufficiently researched? I did not find any information that could answer this 


\section{REVIEW}

question, either on the website or in Hanssen's study. Additionally, the individual event files record neither source nor editor. The reliability of the data is thus uncertain, at least for scholars like me, who only have access to the public version of the database.

Furthermore, the metadata connected to the events appears not always to be sufficiently detailed. For example, Hanssen proposes a map of the 1878 spring and summer productions of Pillars of Society with only one event outside present-day Germany, in Vienna. However, IbsenStage has events with German titles registered for 1878 in today's Polish towns of Marienwerder (event identifier 87431) and Stargard (event identifier 87458 , consulted July 13th, 2019) as well. Looking at the metadata, I found that the field 'Production Nationality' is indicated as 'Germany' (an attribution that in itself is rather problematic); the language field, though, is empty. The same is true for some places that are now German, such as Zwickau (event identifier 87462) or Kaufbeuren (87445). I began to wonder whether this would be the explanation for the absence of these productions on Hanssen's map? Or is the difference between Hanssen's map and the data accessible today through IbsenStage due to updates? Or were the missing events actually fall productions and consequently not noted, impossible for me to see in IbsenStage? Is the missing data from present-day France due to incomplete systematic research, or were there no such events, even if Strasbourg and Metz were laboratories of modernity in their own, well-documented way? At this point, I understood why, in other quantitative studies and in the natural sciences alike, the raw data is usually published on an accessible server-to be available for control by other scholars - and why the process of database creation should be as well documented as possible-to be able to estimate the range of possible error. Hopefully, accessible information on the creation of the database and its sources will be published on IbsenStage's website in the near future.

Having deplored some fundamental methodological problems that might of course have an impact on the detail of Hanssen's 


\section{Ibsen Studies}

results, I must however point out that no other study has so far drawn from such a comprehensive database. That means that even if not all maps and tables appear to be entirely reliable, the general trends described by Hanssen are convincing, and some of them are worthy of discussion here. First of all, Hanssen shows that Ibsen's breakthrough on the German stage was not directly linked to his first box-office success. In fact, as Hanssen discusses in chapter two, Ibsen had a major success with Pillars of Societies, the seventh most played theatrical play on German stages in 1877-78 (p.38) with a total of 67 events recorded in IbsenStage between 1877 and 1881 (p.34). Nevertheless, this success seemed to remain a one-hit wonder as essentially no other play by Ibsen was produced until 1885 after A Doll's House flopped in 1880-81. Hanssen convincingly argues that Pillars of Society was seen more as a sequel to Bjørnsen's $A$ Bankruptcy, which had enjoyed even more success some years before, and to which it was compared in contemporary reviews, not always to Ibsen's advantage (p.45). Pillars of Society was not produced and understood as an innovative modern play, but rather as a conventional well-made play (piece bien faite), partly due to sometimes very loose unauthorized translations of the play, which did not gain much appreciation from the author, but were enjoyed by theaters and production companies. Hanssen shows that many of the productions staged outside subsidized court theaters were in fact based on such unauthorized translations, which also freed them from the obligation of paying royalties to the author.

Unauthorized translations are a leitmotiv in the remainder of Hansson's study, sparking Ibsen's ire as well as box-office successes for many years. Such translations even served as the textual basis for further translations, especially in Eastern Europe and parts of Southern Europe. Hence, the international Ibsen was often not the original Ibsen, but the adapted, misunderstood, transformed Ibsen. The international Ibsen was not as modern and innovative as we now and Ibsen then would have wanted, but he was commercially successful. This is true even for one of his currently most produced plays, Peer Gynt, which experienced 


\section{REVIEW}

a late reception beginning in the $1910 \mathrm{~s}$ - not as a critical satire, but either as expressionist station drama or, more importantly, as a 'metaphysical drama of redemption' (202).

Ibsen in fact became a world dramatist, according to Hanssen's findings, at the time when Ghost was staged by the thêâtre-libre movement. However, although the play was important to naturalist experimenters, modernist authors and theater activists, its success cannot be sufficiently explained by what was, quantitatively, a rather restricted reception. In fact, from 1885 to 1889, 80 German-language productions of nine works are recorded in IbsenStage, A Doll's House coming in first, making up $31 \%$ of all productions. The latter was not presented by any independent theater company nor 'by any of the typical naturalistic stages of the German-speaking areas' (103). Ibsen's works were commercial successes in many private and municipal theaters that received few or no subsidies. Ibsen could thus be understood as an innovative author useful for 'antibourgeois, anti-establishment theatre experiments' in some contexts and as a successful bourgeois author in others. Even a play restricted by Prussian censorship such as Ghosts was played in Frankfurt, Basel, Bern, and Chicago without any documented problems (101).

What was the reason for Ibsen's success, then? Hanssen convincingly suggests that it was a result of quite complex dynamics caused by actors in entangled fields. Besides concerted actions such as Ibsen-Weeks, with several productions in one town at the same time, touring companies and solo-star actors and actresses were most importantly responsible for disseminating Ibsen's work in the German-speaking world, as Hanssen shows in detail. Several famous actresses toured with A Doll's House, acting often with different local ensembles. The public came to see the actress, but got Ibsen as well; furthermore, a variety of regional theaters and theater companies became part of an Ibsen network in the process. Theatrical literary agencies and book editors-authorized or otherwise-began to follow Ibsen's writings closely and promote his new plays as Ibsen plays (and not just as Norwegian or Scandinavian works). A large network of more or 


\section{Ibsen Studies}

less loosely linked actors from the fields of theater and literature began to gain interest in Ibsen as a means to gain money and/or symbolic capital. His plays were staged for long stretches of time, and the new ones did not necessarily replace the older ones; they seem to have merely sustained interest in Ibsen's work in general. Until the 1910s, A Doll's House remaining the most staged play.

As these all-too-brief remarks suggest, Hanssen's study is an important contribution to Ibsen and historical theater studies. It proves the efficiency and possibilities of new quantitative approaches in spite of some methodological shortcomings. It nuances and enriches our historical and sociological knowledge of the making of Ibsen as a world dramatist in a fascinating manner. Hopefully, other scholars will take up the challenge to follow his reception in a similar way for other parts of the world so that we might get a fuller understanding of Ibsen as part of the world's literature, of which Hanssen can only give us an engrossing glance here.

Thomas Mohnike Professor of Scandinavian Studies, University of Strasbourg, France tmohnike@unistra.fr

Check for updates 